\title{
Etiología de las neumonías adquiridas en comunidad en la población infantil
}

\author{
Dra. Olga Morales', Harold Durango², Yenny González ${ }^{3}$
}

\author{
I Neumóloga Pediatra. Docente Departamento de Pediatría y Puericultura. Universidad de Antioquia. Colombia. \\ 2 Bacteriólogo y Laboratorista Clínico. Especialista Micología Médica, MsC en Microbiología y Bioanálisis. \\ Docente Departamento de Pediatría y Puericultura. Universidad de Antioquia. Colombia. \\ 3 Microbióloga y bioanalista. Especialista auditoría en salud. Docente Departamento de Pediatría y Puericultura. \\ Universidad de Antioquia. Colombia.
}

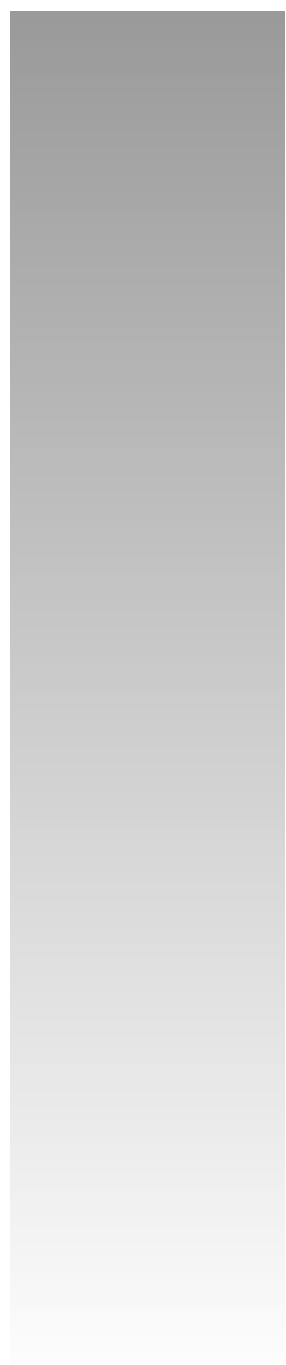

\section{ETIOLOGY IN COMMUNITY ACQUIRED PNEUMONIA IN CHILDREN POPULATION}

Respiratory infections of lower respiratory tract remain a major cause of mortality in young children worldwide, particularly in developing countries. The Community Acquired Pneumonia (CAP), the infectious etiology pneumonia acquired by a previously healthy individual outside a hospital. In 2012, WHO stated that S. pneumoniae and $H$. influenzae type $b(\mathrm{Hib})$ are the first and second most common cause of bacterial pneumonia in children, respectively, whereas Respiratory Syncytial Virus is the most frequent cause of viral pneumonia. The assessment and treatment of a child with a respiratory infection of lower airways becomes a challenge as not only the clinical manifestations of infection by viruses, bacteria or atypical bacteria may overlap, but also coinfections occur frequently. The etiological agents of pneumonia in children can be divided into three groups: common bacteria (S. pneumoniae, $H$. influenzae, S. aureus, M. catarrhalis, S. pyogenes, B. pertussis, M. tuberculosis, among others), respiratory viruses (RSV, Influenza A and B, Parainfluenza I, 2 and 3, Adenovirus, Rhinovirus, Coronavirus, Metapneumovirus, Bocavirus, Enterovirus, Varicella Zoster, among others) and atypical pathogens (M. pneumoniae, C. pneumoniae, C. trachomatis, L. pneumophila, C. burnetii, among others). The etiological diagnosis of CAP in pediatric patients is supported by laboratory tests that generate direct or indirect evidence of the causal germ. The search for the causing agent becomes a challenge, primarily due to the limitation in obtaining appropriate samples and the difficulty to identify the etiological agent and differentiate between colonization and infection. With the available methods, a specific germ is expected to be detected from 16 to $85 \%$ of the cases, making it difficult to determine the true incidence of these infections. In addition, the variety of diagnostic techniques used in clinical trials and interpretation of the results in the absence of germ isolation makes it even more difficult to determine the true incidence of the CAP etiologic agents.

Key words: Community Acquired Pneumonia, etiology, children.

\section{RESUMEN}

Las infecciones respiratorias de vías aéreas inferiores siguen siendo una de las principales causas de mortalidad en niños pequeños alrededor del mundo, particularmente en países en desarrollo. La Neumonía Adquirida en la Comunidad (NAC), es la neumonía de etiología infecciosa que adquiere un individuo previamente sano, fuera de un hospital. En el 20 12, la OMS, establece que S. pneumoniae y $H$. influenzae tipo b (Hib) son la primera y segunda causa más común de etiología bacteriana en niños, respectivamente; mientras que el Virus Sincitial Respiratorio es la causa más frecuente de neumonía viral. La evaluación y el manejo de un niño con una infección respiratoria de vías aéreas inferiores, se convierte un reto ya que no sólo las manifestaciones clínicas de las infecciones por virus, bacterias o bacterias atípicas pueden solaparse, sino que también ocurren frecuentemente coinfecciones. Los agentes etiológicos de las neumonías en niños se pueden dividir en 3 grupos: bacterias comunes (S. pneumoniae, $H$. influenza, S. aureus, M. catarrhalis, S. pyogenes, B. pertussis, M. tuberculosis, entre otros), virus respiratorios (VSR, Influenza A y B, Parainfluenza I, 2 y 3, Adenovirus, Rhinovirus, Coronavirus, Metapneumovirus, Bocavirus, Enterovirus, Varicela, entre otros) y gérmenes atípicos (M. pneumoniae, C. pneumoniae, C. trachomatis, $L$.

Correspondencia: Dra. Olga Lucía Morales Múnera. Neumóloga Pediatra. Docente

Departamento de Pediatría y Puericultura. Universidad de Antioquia.

Calle 67 \# 51-27, Bloque I |-50 I. Departamento de Pediatría. Hospital Universitario

San Vicente Fundación. Medellín, Antioquia. Colombia.

Teléfono: 2192480.

E-mail: olmmunera@yahoo.com 
pneumophila, Coxiella burnetii, entre otros). El diagnóstico etiológico de NAC en el paciente pediátrico se apoya en pruebas de laboratorio que generan una evidencia directa o indirecta del germen causal. La búsqueda del agente causal se convierte en un reto debido principalmente a la limitación para obtener muestras adecuadas y a la dificultad de identificar el agente etiológico y diferenciar entre colonización e infección. Con los métodos disponibles se estima que se puede detectar un germen específico entre el 16 al $85 \%$ de los casos; lo cual dificulta la determinación de la incidencia real de estas infecciones; además, la variedad de técnicas diagnósticas utilizadas en los estudios clínicos y la interpretación de los resultados en ausencia de aislamiento de un germen hacen aún más difícil la determinación de la incidencia real de los agentes etiológicos de la NAC.

Palabras clave: Neumonía adquirida en la comunidad, etiología, virus, bacterias, factores de riesgo, diagnóstico.

\section{INTRODUCCIÓN}

Las infecciones respiratorias agudas (IRA) que afectan el tracto respiratorio inferior son una de las principales causas de mortalidad en niños alrededor del mundo, particularmente en países en desarrollo, causando aproximadamente un tercio de todas las muertes estimadas en niños menores de 5 años. El promedio de episodios de infección respiratoria al año es de 7 en niños menores de 5 años y aproximadamente 3 en adultos ${ }^{(1)}$.

La neumonía adquirida en la comunidad (NAC), se define como la neumonía de etiología infecciosa que adquiere un individuo previamente sano, fuera de un hospital. NAC es una de las infecciones más comunes en los niños, con una incidencia de 34 a 40 casos por cada 1.000 niños en Europa y Norte América ${ }^{(2)}$. Aunque la mortalidad atribuible a NAC en los países industrializados es poco frecuente, esta entidad sigue siendo una de las principales causas de mortalidad en los países en desarrollo(3). En la década de los ochenta se implementaron varias estrategias para el control de las neumonías, tales como: la ampliación de la cobertura de vacunación contra sarampión y tosferina y la estandarización del diagnóstico y tratamiento. Por otro lado, la Atención Integrada de las Enfermedades Prevalentes de la Infancia (AIEPI), incorporó como parte de sus estrategias, la promoción del diagnóstico y tratamiento antibiótico temprano dirigidos al control de las neumonías(2).

La Organización Mundial de la Salud (OMS) en el 2010, estableció que cada año mueren 7,6 millones de niños menores de cinco años, siendo la neumonía una de las principales causas, seguida por diarrea, paludismo y los problemas de salud durante el primer mes de vida, donde la desnutrición afecta un tercio de esta población. La probabilidad de morir antes de los 5 años es 18 veces más alta en niños de países con ingresos económicos bajos que en niños que viven en países con ingresos económicos altos ${ }^{(4,5)}$. Se ha establecido que la mortalidad por neumonía alrededor del mundo es de 4 millones en niños, de las cuales el 90\% ocurren en países en vía de desarrollo, siendo la etiología bacteriana la más importante(6). En este mismo grupo poblacional, se ha establecido que la letalidad de esta entidad fluctúa entre $0,004 \%$ y $24 \%$ de acuerdo al grado de desarrollo del país $s^{(7)}$. La incidencia mundial de neumonía ha sido estimada entre 1.000 y 12.000 por 100.000 niños; con un porcentaje de hospitalización que va del 22 al 50\%(6). En países como España la tasa de presentación de las neumonías va de 30,3 a 36 casos por 1.000 niños menores de 6 años, pero la incidencia de dichas neumonías es menor en niños mayores, con II a 16 casos por 1.000 niños $^{(8)}$.
En América Latina y del Caribe, la IRA está ubicada entre las primeras cinco causas de muerte en niños menores de 5 años y representa la causa principal de morbilidad y asistencia a los servicios de urgencias y consulta externa en la población pediátrica ${ }^{(4)}$; se estima que más de 80.000 niños menores de 5 años mueren cada año por infecciones del tracto respiratorio bajo, de las cuales el $85 \%$ corresponde a $N A C^{(6)}$. Según estadísticas del 2007, la OMS establece que en América Latina y el Caribe, las neumonías y las infecciones por influenza representan una mortalidad del I I,5\% en niños con edades de 0 a 4 años. Según este mismo estudio, se encontró una incidencia de 919 casos de NAC por cada 100.000 niños menores de 5 años, con una incidencia mayor en los niños menores de 2 años. Alrededor de una cuarta parte de los pacientes con NAC requirieron hospitalización y la duración media de la estancia fue de I I días(6). En el 20 I2, la OMS, hace referencia a que entre los diversos agentes infecciosos (virus, bacterias y hongos) causantes de neumonía, S. pneumoniae y $\mathrm{H}$. influenzae tipo b (Hib) son la primera y segunda causa más común de etiología bacteriana en niños; respectivamente, mientras que el virus sincitial respiratorio es la causa más frecuente de neumonía viral(9).

\section{DEFINICIÓN}

Se define como neumonía, al proceso inflamatorio agudo del parénquima pulmonar con ocupación del espacio aéreo y/o participación intersticial, reconocible radiológicamente, y evidenciado por manifestaciones clínicas dependientes del grupo de edad, del estado nutricional del paciente y de la etiología. La NAC, se define entonces como la neumonía que se identifica en sujetos que no han sido hospitalizados en los últimos 7 días 0 se presenta en las primeras $48 \mathrm{~h}$ de ingreso hospitalario(10,1). Esta definición es más difícil en lactantes por el solapamiento de las manifestaciones clínicas y radiológicas de la NAC con la bronquiolitis. Para la OMS, los engrosamientos peribronquiales y las áreas múltiples de atelectasias e infiltrados parcheados pequeños no deben ser considerados neumonías radiológicas, excepto si se acompañan de derrame pleural(8).

Esta enfermedad puede clasificarse de acuerdo a su ubicación anatómica (alveolar, bronquial o intersticial); al agente etiológico (bacteriana, viral y/o micótica) $)^{(12)}$; a la gravedad de la presentación (leve, moderada o grave) (13); a la respuesta inmune del individuo (neumonía en inmunocompetentes e inmunocomprometidos); o al lugar donde se adquirió la neumonía (adquirida en la comunidad, neumonía asociada al cuidado de la salud) $)^{(12)}$. 


\section{FACTORES ASOCIADOS A LA PRESENTACIÓN DE LA NAC}

Son numerosos los factores de riesgo asociados a la presentación de las neumonías, de los cuales unos son dependientes del huésped, otros dependientes del agente etiológico y otros del ambiente. Entre de los factores relacionados con el huésped, que pueden aumentar el riesgo de neumonías bacterianas están ${ }^{(14)}$ :

I. Anormalidades congénitas anatómicas: paladar hendido, fístula traqueo-esofágica, secuestro pulmonar, otras malformaciones pulmonares, entre otras.

2. Defectos inmunológicos: secundarios a enfermedad adquirida o congénita o al uso de medicamentos.

3. Alteraciones en el aparato mucociliar o a las características del moco: fibrosis quística y disquinesia ciliar primaria.

4. Bronco-aspiración: enfermedad por reflujo gastro-esofágico, trastornos de la deglución, aspiración de cuerpo extraño, alteraciones del estado de conciencia (crisis convulsivas, anestesia, entre otros).

5. Infecciones virales previas.

6. Enfermedades neuromusculares.

7. Dolor por traumatismo o cirugía de tórax y/o abdomen.

8. Vías aéreas artificiales: intubación, ventilación mecánica y traqueostomía.
9. Otras entidades como: cardiopatías congénitas, displasia broncopulmonar, desordenes gastro-intestinales, asma, sinusitis, otitis media aguda, entre otros.

10. Otras condiciones como: prematuridad, desnutrición, sexo masculino, bajo peso al nacer, los cambios de la microbiota normal de la nasofaringe y la orofaringe, la elevación del pH gástrico (antiácidos, antagonistas de receptores $\mathrm{H}_{2}$ e inhibidores de la bomba de protones) ${ }^{(10,15)}$.

En cuanto al agente etiológico como factor de riesgo para la presentación de las neumonías están: el tipo de microorganismo, su virulencia, la cantidad de inóculo y el potencial epidémico del germen implicado ${ }^{(8,13)}$. Entre los factores de riesgo relacionados con el ambiente están: la estacionalidad dado que el aumento en la incidencia de las neumonías se presentan en los meses fríos, por la mayor circulación de agentes virales y un mayor nivel de hacinamiento entre los niños (Tabla I); el bajo nivel socioeconómico, las madre adolescente y con baja escolaridad, el incumplimiento en el plan de vacunación, las hospitalización prolongada, la lactancia materna de menos de 3 meses, la asistencia a guarderías, el tabaquismo pasivo y/o la exposición a contaminantes ambientales ${ }^{(4-6)}$

Es de resaltar que en el recién nacido hay unos factores de riesgo inherentes a su condición, los cuales favorecen la

Tabla I. Estacionalidad y potencial epidémico de los principales agentes etiológicos de NAC

\begin{tabular}{|c|c|}
\hline Microorganismo & Estacionalidad \\
\hline Virus sincitial respiratorio & $\begin{array}{l}\text { Epidemias cada año entre noviembre y mayo, con picos } \\
\text { entre enero y febrero, con amplia variación geográfica } \\
\text { y temporal e influenciadas por factores climáticos y de } \\
\text { inmunidad }\end{array}$ \\
\hline Influenza & $\begin{array}{l}\text { Epidemias anuales de Influenza A con mayor circulación } \\
\text { en meses de invierno. Influenza B con ciclos cada } 3 \text { a } \\
4 \text { años }\end{array}$ \\
\hline Parainfluenza & $\begin{array}{l}\text { Se presenta en brotes epidémicos anuales o bianuales: } \\
\text { Tipo I: Principio de otoño (patrón bianual) } \\
\text { Tipo 2: Final otoño-invierno } \\
\text { Tipo 3: Primavera-verano } \\
\text { Tipo 4: Variable }\end{array}$ \\
\hline Rhinovirus & $\begin{array}{l}\text { Circula de forma significativa durante el año excepto, en } \\
\text { los meses de verano }\end{array}$ \\
\hline Adenovirus & $\begin{array}{l}\text { No tiene patrón estacional definido sin embargo, se } \\
\text { presentan brotes esporádicos más frecuentes en los } \\
\text { primeros } 6 \text { meses del año }\end{array}$ \\
\hline Metapneumovirus & $\begin{array}{l}\text { Epidemias anuales con picos al final del invierno y prin- } \\
\text { cipio de la primavera }\end{array}$ \\
\hline Streptococcus pneumoniae & $\begin{array}{l}\text { Infección influenciada por factores climáticos y circulación } \\
\text { viral. Se presenta de forma variable durante el año pero } \\
\text { fuera de los meses de verano }\end{array}$ \\
\hline Mycoplasma pneumoniae & $\begin{array}{l}\text { Circula de forma endémica con epidemias entre } 3 \text { a } 7 \\
\text { años, se da frecuentemente a finales del verano y prin- } \\
\text { cipios del otoño }\end{array}$ \\
\hline
\end{tabular}

Adaptado de Clark y cols ${ }^{(50)}$

\section{Potencial epidémico}

Anualmente cambian los genotipos que circulan de forma predominante. La gravedad y la incidencia varían entre temporadas

Las epidemias anuales se asocian a alteraciones de su estructura genética. Las pandemias están relacionadas con los cambios antigénicos mayores

Los brotes intrahospitalarios son debidos al tipo 3 el cual tiene una alta virulencia

Circulación marcada al comienzo de la escolarización

Produce brotes epidémicos en comunidades cerradas

Circula de forma predominante dos genotipos con diferencias locales

Produce brotes epidémicos ocasionales. Los serotipos más frecuentes son: I, 5 y 14 en niños, mientras que en adultos son: 8 y $12 \mathrm{~F}$

Produce brotes frecuentes en instituciones cerradas $y$ en comunidad. Es de alta transmisibilidad 
presentación de dichas infecciones, dentro de estos se incluyen: prematuridad, bajo peso al nacer, sexo masculino, ruptura de membranas mayor de 24 h, colonización del tracto genitourinario en la gestante y la corioamnionitis( ${ }^{(5)}$.

\section{FISIOPATOLOGÍA DE NAC}

Las vías aéreas normalmente son estériles desde el área subglótica hasta el parénquima pulmonar. Los pulmones están protegidos de las infecciones por una serie de mecanismos de defensa dentro de los que están, las barreras anatómicas y mecánicas (la filtración del aire por las fosas nasales, el reflejo de la tos, el estornudo y el aparato muco-ciliar), los factores locales y la inmunidad (secreción local de inmunoglobulina A secretora, complemento, antiproteasas, opsoninas, lactoferrina, macrófagos alveolares, neutrófilos y células asesinas naturales, además de la respuesta inmune mediada por la producción de anticuerpos y respuesta celular específica, que neutralizan y destruyen los microorganismos). Los virus incrementan la susceptibilidad del tracto respiratorio inferior a las infecciones bacterianas, dado que el daño ciliar y la alteración de la respuesta inmune pueden predisponer a la invasión y diseminación bacteriana e incluso pueden llegar a potenciar su efecto; aunque en algunos casos esta teoría no explica totalmente esta ${ }^{(14,16)}$.

La infección del parénquima pulmonar puede ocurrir cuando alguno de los mecanismos de defensa está alterado o cuando el individuo es invadido por un germen virulento( ${ }^{(16)}$. Las bacterias llegan a las vías aéreas inferiores por la inhalación de aerosoles o por la aspiración de la flora comensal de las vías aéreas superiores. En algunas ocasiones la neumonía es producida por microorganismos que llegan al pulmón por vía hematógena, a partir de otro foco infeccioso distante o por contigüidad en el caso de abscesos hepáticos, o por penetración en caso de trauma. Los recién nacidos pueden adquirir la infección por la aspiración del germen en el canal del parto, por bacteriemia materna antes del parto o durante el nacimiento o por contaminación luego del parto (fuentes humanas o material contaminado) $)^{(14,16)}$.

La invasión bacteriana del parénquima pulmonar lleva inicialmente a vasodilatación, con el aumento en el reclutamiento celular, a esta fase se denomina inflama- ción; posteriormente persiste la congestión y el aumento de la permeabilidad vascular con paso de exudado intraalveolar, depósito de fibrina e infiltrado de neutrófilos, a esta etapa se conoce como "hepatización roja". Este fenómeno lleva al aumento de shunt y trastornos de la ventilación perfusión, que se traduce en hipoxemia, y alteración en el gasto cardíaco. Luego hay un predominio de depósitos de fibrina con progresiva desintegración de las células inflamatorias, denominándose esta etapa como "hepatización gris". En la mayoría de los casos, la consolidación se resuelve de 8 a 10 días por digestión enzimática con reabsorción o eliminación por la tos a esta etapa se denomina "resolución". Si la infección bacteriana no se resuelve se puede presentar absceso pulmonar o empiema $^{(14-17) \text {. }}$

\section{AGENTES ETIOLÓGICOS}

Los agentes etiológicos de las neumonías en niños (Tabla 2) se pueden dividir en 3 grupos: bacterias comunes (Streptococcus pneumoniae, Haemophilus influenza, Staphylococcus aureus, Moraxella catarrhalis, Streptococcus pyogenes, Bordetella pertussis, Mycobacterium tuberculosis, entre otros), virus respiratorios (VSR, Influenza A y B, Parainfluenza I, 2 y 3, Adenovirus, Rhinovirus, Coronavirus, Metapneumovirus, Bocavirus, Enterovirus, Varicela, entre otros) y gérmenes atípicos (Mycoplasma pneumoniae, Chlamydophila pneumoniae, Chlamydia trachomatis, Legionella pneumophila, Coxiella burnetii, entre otros) $)^{(10,18) .}$

Los agentes más frecuentemente involucrados en la coinfección son: $S$. pneumoniae, S. aureus y los virus como VRS e Influenza $A$ y $B^{(8)}$. Hay evidencias de que la coinfección de Influenza y $S$. aureus incrementa la gravedad de la enfermedad. Cuando S. aureus es productos de leucocidina Panton Valentine,

Tabla 2. Agentes etiológicos de las neumonías más frecuentes según el grupo de edad

\begin{tabular}{|c|c|c|}
\hline Edad & Bacterias & Virus \\
\hline $\begin{array}{l}\text { Neonato a } \\
\text { I mes }\end{array}$ & $\begin{array}{l}\text { Streptococcus Beta Hemolítico del grupo B } \\
\text { Escherichia coli } \\
\text { Gram Negativos, bacterias entéricas } \\
\text { Listeria monocytogenes } \\
\text { Chlamydia trachomatis } \\
\text { Staphylococcus aureus } \\
\text { Ureaplasma urealyticum }\end{array}$ & $\begin{array}{l}\text { Citomegalivirus (CMV) } \\
\text { VRS } \\
\text { Herpes virus }\end{array}$ \\
\hline $\begin{array}{l}\text { I mes a } \\
3 \text { meses }\end{array}$ & $\begin{array}{l}\text { Streptococcus pneumoniae } \\
\text { Chlamydia trachomatis } \\
\text { Haemophilus influenzae tipo b } \\
\text { Staphylococcus aureus } \\
\text { Bordetella pertussis } \\
\text { Listeria monocytogenes } \\
\text { Mycoplasma pneumoniae } \\
\text { Pseudomonas aeruginosa }\end{array}$ & $\begin{array}{l}\text { VRS } \\
\text { Virus de Influenza A y B } \\
\text { Virus de Parainfluenza } \\
\text { Adenovirus } \\
\text { Metapneumovirus }\end{array}$ \\
\hline $\begin{array}{l}4 \text { meses a } \\
4 \text { años }\end{array}$ & $\begin{array}{l}\text { Streptococcus pneumoniae } \\
\text { Haemophilus influenzae tipo b } \\
\text { Mycoplasma pneumoniae } \\
\text { Mycobacterium tuberculosis }\end{array}$ & $\begin{array}{l}\text { Virus Sincitial respiratorio (VRS) } \\
\text { Virus de Influenza A y B } \\
\text { Virus de Parainfluenza } \\
\text { Adenovirus } \\
\text { Metapneumovirus } \\
\text { Rhinovirus }\end{array}$ \\
\hline $\begin{array}{l}5 \text { años a } \\
12 \text { años }\end{array}$ & $\begin{array}{l}\text { Streptococcus pneumoniae } \\
\text { Mycoplasma pneumoniae } \\
\text { Chlamydophila pneumoniae } \\
\text { Coxiella burnetti } \\
\text { Mycobacterium tuberculosis }\end{array}$ & Virus de Influenza A y B \\
\hline
\end{tabular}

Adaptado de Cobos y cols ${ }^{(1)}$. 
se presenta neumonía necrotizante. Además, se ha demostrado sinergia entre Influenza y S. pneumoniae por múltiples mecanismos patogénicos ${ }^{(8,10,18)}$.

Hay pocos estudios dedicados a la búsqueda de la etiología de las neumonías en pediatría, sin embargo, en un estudio realizado en Perú (Padilla y cols 2010), identificó sólo un patógeno en $63,7 \%$ de los niños y se presentó co-infección en el II,9\% de estos casos, de los cuales el 10,4\% tuvieron infección mixta, viral y bacteriana ${ }^{(3)}$. En un estudio realizado en Turbo-Colombia (Valencia y col, 2004) se encontró que el $16 \%$ de los niños menores de 5 años tenían cultivo positivo para alguno de los patógenos respiratorios ${ }^{(19)}$. En Uruguay, en un estudio realizado entre 1998 y el 2004, se encontró que el 13,5\% de las neumonías eran de etiología bacteriana y $\mathrm{S}$. pneumoniae causó el $92 \%$ de ellas ${ }^{(20)}$.

En un estudio realizado en Finlandia (Honkinen y cols, 20I I), en 76 niños con edad promedio de 4,7 años, utilizando esputo inducido como muestra, el germen fue identificado en 74 (97\%) de los pacientes; los virus fueron identificados en 55 (72\%) y las bacterias fueron identificadas en 69 (91\%) de los niños estudiados. Las infecciones mixtas estuvieron presentes en el $66 \%$ de los pacientes, la combinación más común de virus y bacterias fue Rhinovirus y $S$. pneumoniae. Los virus más frecuentemente identificados fueron el VRS, Rhinovirus, Bocavirus humanos y Parainfluenza; aunque se debe tener en cuenta que los virus pueden no ser los causantes de las neumonías, dado que pueden ser detectados en pacientes asintomáticos, puede estar presente en infecciones concomitante del tracto respiratorio superior, o podría deberse a la excreción prolongada de un virus, como en el caso de los enterovirus ${ }^{(21,22) .}$.

En un meta-análisis realizado para Latino América y el Caribe, se estableció la frecuencia de la etiología bacteriana para países con bajos ingresos, $H$. influenzae es el responsable del 12\% de los casos, S. aureus del 6, I al 19,5\% y S. pneumoniae del 8,9\%; estos fueron los microorganismos más frecuentes, teniendo en cuenta que hay pocos estudios que evidencien estas etiologías; mientras que en los países con ingreso medio de la misma área geográfica, se presentó un predominio de $S$. pneumoniae con $12 \%$, seguido por $M$. pneumoniae con 3,8\% y H. influenzae con $2,6 \%$ de los $\operatorname{casos}^{(6)}$. Los virus respiratorios representan el mayor porcentaje de agentes causantes de NAC, de 14 a $62 \%$, siendo más frecuente en niños menores de 2 años ${ }^{(8,23)}$.

Aproximadamente, entre $20-30 \%$ de las NAC son causadas por infecciones mixtas (virus y/o bacteria) y el $\mathrm{S}$. pneumoniae es la bacteria más frecuentemente implicada ${ }^{(12)}$. Las infecciones mixtas por virales y bacteria o bacteria y bacteria o virus y virus se identifican en proporciones variables, y son más frecuentes en menores de 2 años ${ }^{(8,18)}$.

La valoración de las coinfecciones (codetecciones) virales y su relación con la gravedad del proceso es un tema difícil de valorar y en el que existen discrepancias. No obstante, parece existir una relación entre la gravedad de la enfermedad, la coinfección y la carga viral. Probablemente, este grado de gravedad esté también sujeto a factores medioambientales, genéticos e incluso de cada tipo de coinfección, según las distintas asociaciones virales que pueden producirse ${ }^{(8)}$.

Según el grupo de edad, los gérmenes identificados con mayor frecuencia son: En el recién nacido, los agentes más importantes son los que colonizan el tracto genital femenino como Streptococcus agalactiae, Escherichia coli, Klebsiella pneumoniae, Listeria monocytogenes y Chlamydia trachomatis. Otros gérmenes que pueden estar presentes en este grupo de edad son Citomegalovirus, Mycoplasma hominis y en menor frecuencia Ureaplasma urealyticum y Herpes simplex(II).

En las neumonías del lactante (2 meses a 2 años) se puede llegar a identificar algún agente causal en el 60 a 70\% de los casos; en el $75 \%$ de estas se ha identificado un solo agente patógeno y en el $20 \%$ existe coinfección ${ }^{(24)}$. En este grupo de edad los virus son la causa más frecuente de neumonías, disminuyendo su incidencia en forma importante con los años, estos virus tienen un comportamiento estacional(3,24). El virus más prevalente en este grupo de edad es el VRS, pero otros virus como Influenza A y B, Adenovirus, puede producir enfermedades graves. Rhinovirus, Enterovirus, Parainfluenza, Coronavirus, Bocavirus y Metapneumovirus, también pueden estar implicados $(3,19,23,25)$.

La principal bacteria identificada en niños desde el primer mes de vida hasta los 6 años y que se mantiene estable en todos los grupos de edad es $S$. pneumoniae ${ }^{(6,23)}$. Otras bacterias como $S$. aureus, $H$. influenzae, $M$. pneumoniae, $M$. catarrhalis, C. trachomatis y Klebsiella spp., también se pueden identificar en este grupo de edad $d^{(6,19,24,26)}$. Bortetella pertussis aunque puede ser agente etiológico de neumonías con compromiso intersticial, tiene un comportamiento clínico que la hace distinguible de los otros agentes ${ }^{(24)}$. En los mayores de 6 años, M. pneumoniae es el principal agente causal, siendo poco frecuente en niños más pequeños ${ }^{(27)}$. En la Tabla 3 se describen los principales microorganismo de acuerdo a los grupos en los cuales se aíslan con mayor frecuencia.

\section{CARACTERÍSTICAS DE LOS PRINCIPALES AGENTES ETIOLÓGICOS}

\section{Agentes virales}

Las neumonías de etiología viral, suelen manifestarse con fiebre, tos y afectación del estado general con una gravedad variable. En la auscultación se puede identificar sibilancias o crépitos finos en forma difusa. Comparadas con las de etiología bacteriana, las de etiología viral suelen presentarse con una evolución clínica más prolongada e insidiosa, con componente broncobstructivo predominante; usualmente están precedidas por una infección de vías aéreas altas seguida de un compromiso de vías respiratorias bajas ${ }^{(27)}$.

\section{Virus Respiratorio Sincitial}

El Virus Respiratorio Sincitial (VRS), después de su primer aislamiento en un lactante con neumonía en 1956, ha sido reconocido como el principal agente etiológico de la infección del tracto respiratorio bajo en lactantes y niños pequeños ${ }^{(4)}$. Este virus se clasifica dentro de la familia Paramixoviridae y el género Pneumovirus. La partícula viral es envuelta y más pequeña que el resto de los paramixovirus, la nucleocápside es de simetría helicoidal y posee como genoma ARN monocatenario de polaridad negativa, no segmentado y codifica para 10 proteínas. El orden de la transcripción de los genes es NSI y 
Tabla 3. Características relevantes de los principales virus respiratorios

\begin{tabular}{|lllclcl|}
\hline Virus & Familia & Genoma & Tamaño (nm) & Simetría & Envoltura & Replicación \\
Influenza A, B, C & Orthomixoviridae & ARN (+), CS segmentado & 100 & Helicoidal & Sí & Núcleo y citoplasma \\
VSR, Parainfluenza I-4 & Paramixoviridae & ARN (-), CS & $150-200$ & Helicoidal & Sí & Citoplasma \\
$\begin{array}{l}\text { Rhinovirus, Coxsackievirus, } \\
\text { Echovirus }\end{array}$ & Picornaviridae & ARN (+), CS & 30 & Icosaédrica & No & Citoplasma \\
$\begin{array}{l}\text { Coronavirus } \\
\text { Adenovirus }\end{array}$ & Coronaviridae & ARN (+), CS & $60-220$ & Helicoidal & Sí & Citoplasma \\
Reovirus & Adenoviridae & ADN, CD & $80-90$ & Icosaédrica & No & Núcleo \\
\hline
\end{tabular}

CS: cadena sencilla, CD: cadena doble, nm: Nanómetros, VSR: virus sincitial respiratoiro. Adaptado de Rosete y $\operatorname{cols}^{(28)}$.

NS2, correspondientes a las proteínas no estructurales, gen de la nucleoproteína $(\mathrm{N})$, de la fosfoproteína $(\mathrm{P})$, de matriz no glicosilada $(M)$, pequeña proteína hidrofóbica (SH), gen de la glicoproteína de unión $(\mathrm{G})$, gen de la glicoproteína de fusión ( $F)$ y gen de la polimerasa o proteína $(\mathrm{L})$, también conocida como proteína larga. Las proteínas SH, G y F forman parte de la envoltura del virión; estas últimas son las que inducen los anticuerpos neutralizantes ${ }^{(28,29)}$. La partícula viral es estable aunque muy lábil o sensible a los cambios de temperatura y pierde más del $90 \%$ de su infectividad en un proceso de congelación y descongelación.

En el VRS se reconocen dos subgrupos antigénicos que pueden definirse por su reacción con anticuerpos monoclonales. Ambos subgrupos muestran una gran variabilidad antigénica intergrupo e intragrupo. El espectro de trastornos respiratorios producidos por el VRS va desde un resfriado común en adultos, hasta cuadros de bronquiolitis en lactantes y neumonía en niños y adultos mayores. Este virus es el responsable del $40 \%$ de las bronquiolitis y del $25 \%$ de todas las neumonías virales, siendo en los lactantes el virus más frecuente en los 6 primeros meses de edad, además que las reinfecciones por este germen suelen ser frecuentes. El período de incubación de la enfermedad es de 4 a 5 días, sin embargo, la excreción viral puede durar hasta 3 semanas $(6,28,29)$

La mortalidad es baja, pero si coexiste con una enfermedad preexistente, la mortalidad puede alcanzar hasta el $37 \%{ }^{(28)}$. Un diagnóstico presuntivo de la infección por VRS en niños, debe estar basado en los síntomas clínicos, la edad y otros factores epidemiológicos, pero el diagnóstico definitivo depende del laboratorio y pudiera dividirse en 2 aspectos fundamentales: detección del virus o de sus componentes y los métodos serológicos.

\section{Adenovirus}

Su nombre deriva del descubrimiento de la partícula viral en cultivos de células de adenoide, en el año 1953. Pertenecen a la familia Adenoviridae, géneros Mastadenovirus y Aviadenovirus; son virus desnudos (estable en el medio ambiente) de simetría icosahedrica, de 70-100 nm de diámetro, contiene DNA de doble cadena lineal como material genético y la cápside se compone de 252 capsómeros, donde doce de ellos se ubican en los vértices formando las fibras que se relacionan con la adherencia a la célula blanco, mientras el resto de los capsómeros forman las paredes del icosahedro. El ciclo replicativo se lleva a cabo dentro del núcleo de la célula huésped y la progenie se libera por lisis celular. Se han descrito 5 I serotipos mediante neutralización y diversos genotipos, los cuales se asocian a una gran variedad de presentaciones clínicas que van desde infecciones persistentes e inaparentes, especialmente en el tejido linfático, hasta infecciones severas que comprometen la vida de los pacientes. Los serotipos que causan cuadros de neumonía son los I, 2, 3, 5, 7 y 21 . Aproximadamente el $65 \%$ de los aislamientos de Adenovirus se presentan en niños menores de 4 años, causando el $10 \%$ de las infecciones respiratorias que requieren hospitalización en este grupo de edad ${ }^{(28)}$.

La enfermedad respiratoria aguda se caracteriza por fiebre, tos, faringitis y adenitis cervical. Es agente importante de neumonías agudas tanto en adultos como en niños, dándose en este último grupo como la manifestación clínica más grave, por ser potencialmente fatal. También se ha asociado con un cuadro clínico parecido al coqueluche, caracterizado por un curso clínico prolongado, debido principalmente al serotipo 5. La infección respiratoria aguda por Adenovirus no difiere inicialmente de la que causan otros virus, especialmente el VRS, aunque determina mayor frecuencia de neumonía con consolidaciones en el parénquima pulmonar, los síntomas catarrales son menos importantes. Se han descrito las secuelas de daño pulmonar residual importante como bronquiectasias y bronquiolitis obliterante ${ }^{(28,30)}$.

\section{Rhinovirus}

Los Rhinovirus humanos (RVH) son los agentes causales más frecuentes de resfriado común. También están asociados con otitis media aguda en niños y sinusitis en adultos. Estos virus, descubiertos en 1956, pertenecen a la familia Picornaviridae, género Enterovirus. Poseen un genoma ARN de cadena simple de 7,2 kb, de polaridad positiva con un único marco de lectura. Es desnudo y de simetría icosaédrica, su capside está compuesta de 60 capsomeros cada uno de los cuales presenta 4 proteínas estructurales con capacidad antigénica inestable (se comportan como antígeno de grupo específico); estas proteínas son: VP I (actúa como sitio de fijación de anticuerpo), VP 2 (Es un Poro), VP 3 (sitio de fijación para AC) y VP 4 (Acompaña al ARN viral). Actualmente, existen descritos más de 100 serotipos clasificados en tres especies: $A, B$ y $C^{(28,31)}$. 
El impacto y la asociación de RVH con diferentes cuadros clínicos han sido subestimados debido a la falta de métodos diagnósticos suficientemente sensibles y específicos. El diagnóstico puede realizarse por aislamiento en cultivo de células, ya que producen efecto citopático y se pueden diferenciar de otros picornavirus por su labilidad al tratamiento con ácido. Sin embargo, algunos serotipos, incluyendo las cepas de la especie C, no crecen en cultivo. Además, el aislamiento en cultivo es costoso, muy laborioso y complejo, e implica la disponibilidad de un área de cultivo celular en el laboratorio de rutina. La detección directa de antígenos por inmunofluorescencia no puede utilizarse para su diagnóstico, dado que no existen anticuerpos monoclonales específicos para todos los RVH por la alta variabilidad antigénica(30,32).

La incorporación de métodos diagnósticos basados en la transcripción inversa y la reacción en cadena de la polimerasa (PCR) han aumentado la sensibilidad de su detección permitiendo asociar a los RVH con infecciones respiratorias, no sólo del tracto superior sino también del inferior, tales como neumonía y bronquiolitis en niños. Asimismo, se les ha detectado en pacientes con exacerbaciones de asma (en niños y adultos), exacerbaciones del cuadro respiratorio en pacientes con fibrosis quística y con enfermedad pulmonar obstructiva crónica (en adultos). Además, la infección por $\mathrm{RVH}$ durante la infancia ha sido identificada como predictor de sibilancias recurrentes, y de posterior desarrollo de asma en niños $^{(18,30,31,33)}$.

\section{Parainfluenzae}

Los virus Parainfluenza del ser humano (VPIh) pertenecen a la familia Paramixoviridae, al igual que el VRS y el Metapneumovirus. Son de simetría helicoidal con un diámetro de 100-200 nm, son envueltos y tienen como genoma ARN de cadena simple, lineal de polaridad negativa y no segmentado. Contienen aproximadamente 15.000 nucleótidos y se han descrito cinco tipos: I, 2, 3, 4a y 4b, de los cuales los serotipos 1, 2 y 3 son los más importantes desde el punto de vista médico, ya que ocupan el segundo lugar dentro de las causas de infecciones respiratorias severas en lactantes y niños pequeños, sólo superados por el VRS ${ }^{(28)}$. Los viriones se encuentran rodeados por una bicapa lipídica de la cual sobresalen proyecciones constituidas por la glicoproteína HN que presentan función hemaglutinina y neuraminidasa, actividades indispensables para su patogenesis. También poseen proyecciones compuestas por la glicoproteína $F$, responsables de la acción hemolítica y de fusión, lo cual posibilita la unión entre células y la hemólisis en ciertos tipos de eritrocitos ${ }^{(21,28)}$. Los VPIh provocan infecciones respiratorias frecuentes y de gravedad variable, donde las manifestaciones clínicas dependen específicamente del serotipo; sin embargo, también es importante la edad del paciente, el estado inmune y el momento epidemiológico del año. Los niños con infección primaria por VPIh de los tipos I, 2 y 3 pueden presentar cuadros clínicos graves, que varían desde laringotraqueítis y crup (particularmente los tipos I y 2), hasta bronquitis y neumonía; sobre todo con el tipo 3, el cual produce enfermedad grave en lactantes menores de 6 meses. Estudios serológicos han demostrado que el $60 \%$ de los niños a la edad de dos años ya han sido infectados con VPIh tipo 3 y que aproximadamen- te el $80 \%$ ha sido infectado a los 4 años de edad, la mayoría asintomáticos(21,34).

Los serotipos 1 y 2 causan epidemias y se presentan con mayor frecuencia en verano y primavera en el hemisferio norte, infectando principalmente a niños pre-escolares, a diferencia del serotipo 3 que infecta a pacientes de todas las edades; el serotipo 4 es aislado con muy poca frecuencia por lo que ha sido relativamente poco conocido y caracterizado. Este serotipo se asocia usualmente a grados menos severos de la enfermedad, aunque ha sido reportado en enfermedades del tracto respiratorio bajo. La desnutrición, el hacinamiento, el déficit de vitamina A, la falta de lactancia materna y la exposición a humo de tabaco son factores que favorecen la infección $n^{(34,35)}$.

\section{Influenza}

El virus Influenza causa frecuentemente infección respiratoria en los distintos grupos etarios de la población humana en todo el mundo. Puede llevar a enfermedad grave e incluso letal en lactantes, ancianos y pacientes inmunocomprometidos. Pertenece a la familia Orthomixoviridae y posee tres géneros $\mathrm{A}, \mathrm{B}$ y $\mathrm{C}$; formados por los virus influenza $\mathrm{A}, \mathrm{B}$ y $\mathrm{C}$, respectivamente. La partícula viral tiene un diámetro de 50- $120 \mathrm{~nm}$, es envuelta y su manto corresponde a una bicapa lipídica derivada de la membrana celular de la célula huésped que infectó, de ella sobresalen alrededor de 500 espículas conformadas por las glicoproteínas hemaglutinina $(\mathrm{HA})$ y neuraminidasa (NA). Hacia el interior de la partícula viral, existe una capa formada por la proteína matriz (M) y más al interior está la nucleocápside de simetría helicoidal, constituida por los complejos polimerasa y nucleoprotéico que incluye el genoma viral, el cual es una hebra de ácido ribonucleico (ARN), de polaridad negativa, formada por 12.000 a 15.000 nucleótidos y segmentada en 7 (influenza C) u 8 fragmentos (influenza A y B); este material genético codifica para 9 proteínas. Las proteínas NSI y NS2 no son estructurales, NSI es inmunomodulador desencadenando efectos como la inhibición del interferón de tipo I (IFN) en las células infectadas. Las proteínas PA, PBI y PB2 interactúan con el genoma viral constituyendo el complejo nucleoprotéico y sintetizan nuevos ARN virales actuando como ARN polimerasa. La nucleoproteína (NP) se asocia a los segmentos del ARN viral y a las polimerasas, conformando la nucleocapside de simetría helicoidal. La proteína MI forma la matriz y, junto a NP, constituyen el antígeno que permite clasificar los virus influenza en los 3 tipos A, B y C. La hemaglutinina $(H A)$ y la neuraminidasa (NA) son los antígenos de superficie del manto, que determinan su patogenicidad y permite clasificarlos en los diferentes subtipos de virus ${ }^{(28,36)}$.

La hemaglutinina es la glicoproteína de superficie más abundante (80\%); interactua con receptores específicos de la mucosa respiratoria, permitiendo la adsorción del virus a la célula huésped (infectividad). En la naturaleza se han descrito variantes $(\mathrm{HI}-\mathrm{HI}$ 6), de las cuales sólo las $\mathrm{HI}, \mathrm{H} 2$ y H3 afectan al hombre. La neuraminidasa es una enzima capaz de romper la unión del ácido neuramínico (siálico) a la proteína, facilitando la liberación viral; se han detectado 9 variantes de $\mathrm{N}$, de las cuales sólo NI y N2 infectan al humano ${ }^{(36)}$.

El virus Influenza A es capaz de producir enfermedad en 
humanos, equinos, porcinos, focas y aves. Los B y C sólo se asocian a enfermedades humanas, aunque se han detectado casos aislados en animales. La infección se disemina por vía aérea a través de aerosoles o por contacto a través de las manos u objetos contaminados. El período de incubación es corto, de horas a 4 días $^{(30,36)}$.

El cuadro clínico clásico se caracteriza, en adultos y adolescentes, por inicio brusco, con fiebre alta $\left(38-40^{\circ} \mathrm{C}\right)$ y acompañado de mialgias, cefalea, escalofríos, decaimiento, malestar general y fotofobia. Posterior al inicio de la fiebre, aparece obstrucción nasal, tos no productiva, disfagia, faringitis y rinitis; mientras que en los niños pequeños pueden presentar fiebre alta (generalmente $>39,5^{\circ} \mathrm{C}$ ), con grados variables de compromiso del estado general, rinitis, cefalea y odinofagia. Los menores de 5 años presentan particularmente anorexia y síntomas gastrointestinales como vómitos y diarrea. En los recién nacidos el cuadro clínico es muy inespecífico, con fiebre alta, letargia, rechazo alimentario, piel moteada y apneas ${ }^{(37)}$.

El virus llega a la mucosa del aparato respiratorio superior, sobrepasa la acción defensiva de los cilios y el moco, este último es desdoblado mediante la acción de la neuraminidasa (antígeno N), la cual rompe los enlaces de ácido $\mathrm{N}$-acetilneuroamínico. Otra proteína externa del virus, la HA, permite la adsorción viral a receptores celulares que contienen ácido siálico, siendo incorporado a la célula en una vesícula endoplasmática a través de endocitosis. La acidificación de la vesícula cambia la conformación de la HA e induce la fusión del manto viral con la membrana endocítica, liberando al citoplasma el complejo ARN -nucleoproteína (NP)- polimerasas (PA-PBI-PB2), el cual es transportado al núcleo, donde se transcriben los 8 ARN mensajeros que originarán proteínas estructurales y no estructurales (NSI, NS2). Los nuevos viriones se ensamblan en la superficie celular y se liberan por gemación. En este último paso la neuraminidasa juega un papel fundamental de separar el ácido siálico de las glicoproteínas viral y celular, permitiendo la liberación del virus y evitando su aglutinación en la mucosa. Durante este proceso algunas células mueren por efecto del virus o de la respuesta inmune celular mientras que otras permiten varios ciclos replicativos virales ${ }^{(36,38,39)}$.

\section{Agentes bacterianos}

Los gérmenes M. pneumoniae, C. pneumoniae, Legionella spp, generan neumonías atípicas, que cursan generalmente de forma subaguda y sin afectación importante del estado general. La tos es el síntoma predominante y puede estar acompañada de fiebre, mialgias, rinorrea, faringitis y/o miringitis. Hay una pobre correlación entre los abundantes hallazgos semiológicos y la escasa afectación del estado general(40). Mycoplasma pneumoniae y Chlamydia pneumoniae se han identificado en el 6 al 40\% de los casos de NAC y son más habituales en niños entre los 5 a 15 años $(8,11)$.

La infección por Bordetella pertussis debe sospecharse en todos los grupos de edad, en los neonatos y en los lactantes suele ser más severa su presentación, se debe sospechar en niños con esquemas de vacunación incompletos. Se ha identificado un segundo pico de incidencia en pacientes mayores de 12 años, es así como la comunidad europea propone cambiar la vacuna de Td en mayores de 5 años por un refuerzo con Tdpa (con baja carga antigénica)(4l).

Mycobacterium tuberculosis también puede causar la NAC en niños, principalmente en pacientes con factores de riesgo como, inmunosuprimidos, diabetes mellitus y desnutrición. Streptococcus pyogenes, es también un causante de neumonías que debe considerarse, principalmente en neumonías necrotizante o en empiema y en ocasiones después de una varicela. La infección por Legionella pneumophila es relativamente poco común en los niños y puede estar relacionada con brotes endémicos ${ }^{(23)}$. El contacto con algunos animales se asocia con posibles gérmenes, como por ejemplo: Francisella tularensis con los conejos, Chlamydophila psittaci en los pájaros y Coxiella burnetti con las ovejas ${ }^{(1)}$.

\section{Streptococcus pneumoniae}

Las neumonías y otros procesos invasivos por S. pneumoniae siguen siendo causa de mortalidad y morbilidad grave en ambos extremos de la vida(2). Se ha establecido que en niños representa del II-15\% de todas de las neumonías, mientras que en pacientes hospitalizados puede alcanzar del $37-44 \%(8)$. Este agente es un coco Gram positivo de I,2 a I,8 $\mu \mathrm{m}$ de longitud, presenta una forma oval y el extremo distal lanceolado. Poseen una cápsula de polisacárido que permite la tipificación con antisueros específicos. Es inmóvil, no forma endosporas, y es miembro de la familia Streptococcaceae (Figura I). Es un microorganismo anaerobio facultativo y catalasa negativo. Son residentes normales de las vías respiratorias altas en 5-40\% de los seres humanos. Es un patógeno causante de un gran número de infecciones entre las que tenemos (neumonía, bronquiolitis, sinusitis, entre otros) y de procesos invasivos severos (meningitis, sepsis, entre otros), específicamente en ancianos, niños y personas inmunocomprometidas. En los niños, los serotipos 6, I 4, 19 y 23 son causa frecuente de neumonía ${ }^{(42)}$.

La virulencia de $S$. pneumoniae es atribuible principalmente a su capacidad para resistir la opsonización, fagocitosis y destrucción intracelular de las células fagociticas, la cual está dada principalmente por su cápsula de polisacárido(43). Existen al menos 90 tipos capsulares y 23 de estos se encuentran en más del $88 \%$ de las bacteriemias y meningitis por este germen. Como otros factores de virulencia están la neumolisina, proteína citotóxica que se acumula dentro de las células durante el crecimiento y es liberada con la lisis celular por la autolisina. Esta corresponde a una $\mathrm{N}$-acetil-muramoil-L-alanina

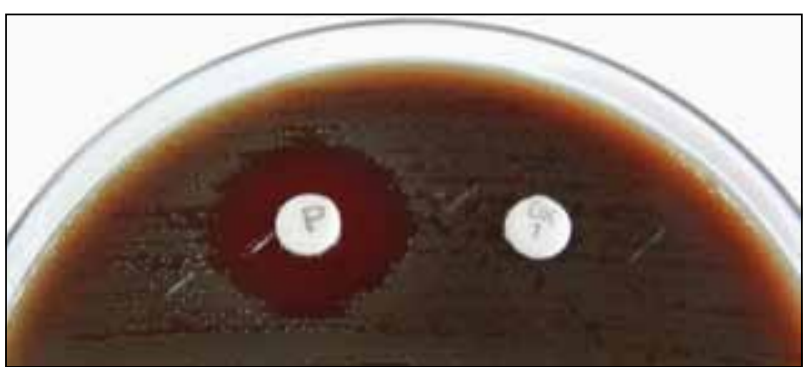

Figura I. Cultivo de Streptococcus pneumoniae, donde se observa la sensibilidad a la optoquina, y el tamizaje con oxacilina de I $\mu$ g revela sensibilidad disminuida a la penicilina. 
amidasa que, junto con una glucosidasa, funciona durante la división celular para separar las células hijas. Algunas cepas neumocócicas también producen hialuronidasa, que facilita la propagación del microrganismo en el tejido y proteasas de Ig-A para la inactivación de esta inmunoglobulina secretora, con el fin de facilitar la colonización y la invasión posterior de las superficies de las mucosas. También se ha caracterizado la proteína de superficie A-PspA, que es antigénica inmunodominante pero se desconoce su función ${ }^{(43)}$.

La distribución de los serotipos de S. pneumoniae y su frecuencia relativa varían no sólo según el área geográfica, con marcadas diferencias entre los países desarrollados y en desarrollo, sino que, cuando se les monitorea a largo plazo, también se observan variaciones en el tiempo ${ }^{(44)}$.

Las manifestaciones clínicas típicas de estos pacientes, pueden ser: fiebre elevada con escalofríos, dolor pleurítico y/o abdominal; generalmente con tos de intensidad variable, la auscultación puede ser normal, o presentar hipoventilación, crépitos y/o soplo tubárico. Actualmente, la disminución de la sensibilidad de S. pneumoniae a los antibióticos de primera elección ha impactado de forma negativa en la salud infantil. El progresivo aumento de la frecuencia de S. pneumoniae resistente a penicilina y a otros antibióticos ha suscitado dudas en torno a las prácticas terapéuticas tradicionales. Por ese motivo, las enfermedades neumocócicas han sido catalogadas como enfermedades emergentes ${ }^{(45,46)}$. Por otro lado, en los países donde se vacunó contra Haemophilus influenzae tipo b, S. pneumoniae adquirió mayor relevancia como causa de neumonías bacterianas en niños ${ }^{(47)}$.

Desde la introducción de las vacunas heptavalente contra neumococo se ha registrado una disminución significativa en los Estados Unidos en el número de ingresos y de neumonías diagnosticadas en atención primaria por este germen, principalmente en los menores de 2 años, pero no en las neumonías complicadas con derrame, las cuales se presentan principalmente en menores de 5 años, además han emergido otros serotipos no incluidos ${ }^{(8)}$. En algunos países como Uruguay la incorporación de la vacuna anti-neumocóccica conjugada de siete serotipos (4, 6B, 9V, I4, I8C, I9F, 23F) en niños menores de cinco años de edad, no ha sido exitosa para solucionar el problema de la neumonía grave en esta población, dado que los serotipos más prevalentes son el 14 , I, 5 y 3 representando el $77 \%$ de los casos confirmados de neumonía neumocóccica, los cuales en su mayoría no están incorporados en la vacuna ${ }^{(27,47)}$, como se muestra en el metaanálisis realizado en América Latina y el Caribe, el serotipo más frecuentemente identificado en todo los grupo de edad, fue el I 4 con una frecuencia que va del 3 I al 55\%, seguido del serotipo I con un 10,9\% y del serotipo 5 con 10,8\%(6).

\section{Haemophilus influenzae}

Haemophilus influenzae ( $\mathrm{Hi})$ es un cocobacilo gram negativo, con apariencia pleomorfica, anaerobio facultativo y necesitan de un ambiente con 5 a $10 \%$ de $\mathrm{CO}_{2}$ para su crecimiento. Pertenece a la familia Pasteurellaceae y la mayoría de las especies necesitan medios de cultivo enriquecidos para su crecimiento, los cuales tiene la presencia de factor $X$ (hemina) y/o factor $V$ (NAD). Es habitante habitual del árbol respiratorio del ser humano y no se conoce otro hospedero.
$H$. influenzae pasa de un hospedero a otro por gotas de saliva y se adquiere poco después del nacimiento. Existen varios tipos, definidos por el antígeno capsular: a, b, c, d, e y f y cepas no tipificables (no encapsuladas). El tipo "b" es el más virulento y responsable de las enfermedades invasivas, generalmente cuando la cantidad de gérmenes que circulan en sangre alcanza altos niveles, es capaz de penetrar las meninges, articulaciones, pleura, pulmón y pericardio. La primera de estas situaciones es la más frecuente. Aún con la terapéutica adecuada, la mortalidad es del $5 \%$ y las secuelas oscilan entre el $20-50 \%{ }^{(43)}$.

Se han descrito distintos factores que facilitan la colonización y el establecimiento de una infección. Entre los factores comúnmente descritos están las adhesinas fimbriadas que reconocen receptores en las células epiteliales de la mucosa, la producción de proteasas de la lgA y factores que inhiben la actividad ciliar de las células epiteliales. En las cepas encapsuladas, la cápsula (polisacárido de polirribosa fosfato) juega un papel importante en la virulencia, debido a su capacidad antifagocitica. La respuesta inmune protectora esta mediada por anticuerpos opsonizantes y activadores de la acción bactericida del complemento(48).

Se estima que $H$. influenzae tipo "b" (Hib), es responsable de unos tres millones de enfermedades graves y de unas 386.000 defunciones anuales, en su mayoría debidas a meningitis y neumonía. Casi todas las víctimas tienen menos de cinco años, y los más vulnerables son los niños entre 4 y 18 meses $^{(49)}$. En los países en desarrollo, en los que se concentran la mayor parte de las defunciones por Hib, la neumonía es responsable de más muertes que la meningitis. Aun así, la meningitis por Hib es también un problema grave en esos países, con tasas de mortalidad superiores a las de los países desarrollados; entre el 15 y el 35\% de los sobrevivientes quedan con discapacidades permanentes como retraso mental o sordera ${ }^{(50)}$.

La enfermedad invasiva por $H$. influenzae (meningitis, sepsis, epiglotitis, celulitis, neumonía, artritis, entre otras) se debe principalmente a cepas productoras de cápsula polisacárida tipo b (Hib). Su incidencia ha disminuido en aquellos países en los que se ha introducido la vacuna conjugada de forma sistemática en el calendario de vacunación(2l). En Estados Unidos, país que introdujo la vacuna en el año 1991, había disminuido la incidencia de enfermedad invasiva en los primeros 5 años de vacunación sistemática en un 99\%, entre los niños menores de 5 años ${ }^{(5 l)}$. En España, la incidencia de enfermedad invasiva por Hib era entre 15,5-20 casos por 100.000 niños menores de 5 años, disminuyendo drásticamente a 0,3/100.000 niños menores de 5 años en 1998, año de inicio de la vacunación sistemática(52).

\section{Staphylococcus aureus}

Conocido comúnmente como Estafilococo dorado, por formar colonias de color amarillo en los medios de cultivo donde crece; pertenece a la familia Micrococaceae, es un coco Gram positivo, anaerobio facultativo, productor de catalasa y coagulasa (la cual estimula la polimerización de la fibrina tras ligarse a la protrombina), inmóvil, manitol positivo, no esporulado y productor de hemolisina (Figura 2$)^{(43)}$. Gran parte de la importancia médica del S. aureus se debe a que es capaz 


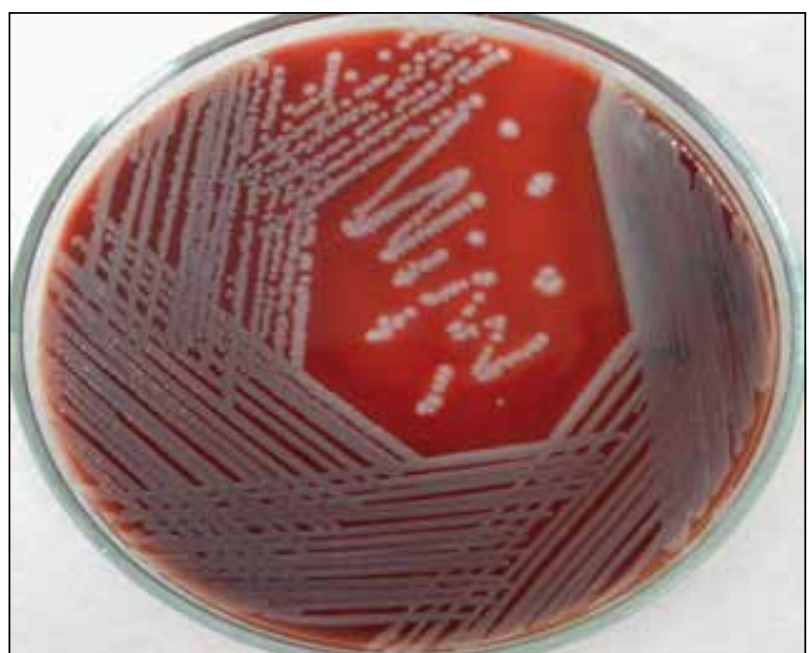

Figura 2. Cultivo en agar sangre donde se observan colonias medianas, $\beta$-hemolíticas, de bordes definidos, blanco-amarillentas, típicas de Staphylococcus aureus.

de sobrevivir en medios con altas concentraciones de sales y temperaturas relativamente altas, es capaz de resistir a la desecación por meses. Se encuentra ampliamente distribuido por todo el mundo, coloniza en forma intermitente la piel y la mucosa de la mayoría de los humanos desde el momento mismo del nacimiento, y hasta en una tercera parte de los casos, dicha colonización es prolongada o permanente; estimándose que una de cada tres personas está colonizada(48).

La composición química de la pared celular de $S$. aureus le permite vivir en ambientes poco favorables y facilita su adhesión a los tejidos del huésped. La mayoría de las cepas tienen una delgada cubierta de lipopolisacarido a manera de cápsula con capacidad antifagocitica. La pared está compuesta por peptidoglicano, ácido teicoico, un polímero fosfatado unido covalentemente al peptidoglicano o a los lípidos de la membrana celular, que media la adherencia de la bacteria al epitelio nasal. La proteína A también exclusiva de este microorganismo, se encuentra unida covalentemente a la capa más externa de peptidoglicano pero puede ser liberada en forma soluble cuando la bacteria penetra los tejidos ${ }^{(43,48)}$.

Las infecciones pulmonares causadas por S. aureus pueden originarse por aspiración o diseminación hematógena desde otro sitio. La neumonía por este microorganismo tiende a presentarse como una enfermedad aguda y grave, en especial porque muchos antibióticos usados para tratar las NAC no proporcionan una cobertura apropiada para este agente. Los hallazgos radiológicos incluyen infiltrados alveolares, los cuales pueden coalescer y originar grandes áreas de consolidación y cavitación. La destrucción de las paredes bronquiales pueden dar lugar a la formación de empiemas o neumatoceles en más del $50 \%$ de los $\operatorname{casos}^{(53)}$.

Aunque la aparición de los neumatoceles puede ser dramática, una vez que la infección es controlada, se resuelven completamente en unos pocos meses. A pesar de su baja frecuencia, estas neumonías precisan ser tratadas conociendo el antibiótico adecuado con base en resultados de antibiograma, pues este germen puede tener cepas meticilinorresistentes, que obligan al uso de fármacos de mayor espectro(53).

\section{Streptococcus pyogenes}

Es un coco Gram positivo en cadena que pertenece a la familia Estreptococcaceae, anaerobio facultativo, inmóvil, $\beta$-hemolítico, perteneciente al grupo A según clasificación del sistema de grupo Lancefield ${ }^{(48)}$. Su principal factor de virulencia es un antígeno de la superficie celular llamado Proteína M, estas son proteínas fimbriales, estables al ácido, termoestables y lábiles a la tripsina y está asociada con las superficie externa de la pared celular. La proteína M está unida a la membrana celular y se extiende a través de la capa de peptidoglicano, proyectándose desde la superficie de la célula bacteriana, presentando propiedades antifagociticas, siendo los subtipos M I, 3, 12 y 28 los más frecuentemente asociados a infecciones graves en pacientes con shock y falla multiorgánica. Se han identificado tres tipos de exotoxinas estreptocócicas: A, B y C. La exotoxina A (más frecuente en Estados Unidos de Norteamérica) y la B (más frecuente en Suecia y Reino Unido) se encuentran en la mayor parte de los pacientes con infecciones graves por $S$. pyogenes ${ }^{(43)}$.

Es el principal agente bacteriano aislado en faringitis aguda, ocasionalmente es el agente causal de neumonía o bacteriemia, generalmente asociado a infecciones virales (Influenza, Sarampión) o a infección por Bordetella pertusis. La neumonía por S. pyogenes es poco frecuente en el adulto con mayor incidencia en niños, en quienes puede ocasionar compromiso parenquimatoso pulmonar y en algunos casos derrame pleural purulento(54).

El microorganismo entra en el pulmón mediante inhalación o microaspiración, en raras ocasiones secundario a diseminación hematógena. Pueden presentarse brotes en ambientes de hacinamiento o en guarderías. El estado de portador de $S$. pyogenes grupo A (SGA) es posible en un pequeño porcentaje de la población sana, siendo transitorio sin ser epidemiológicamente relevante ${ }^{(55)}$. Los mecanismos patogénicos involucrados en la infección grave por $S$. pyogenes han sido parcialmente esclarecidos, donde interactúan los mecanismos de defensa del huésped y los factores específicos de virulencia del microorganismo que son fundamentalmente la proteína M y las exotoxinas ${ }^{(56)}$.

\section{Moraxella catarrhalis}

Son diplococos Gram negativos, pertenecen a la familia Neisseriaceae aerobios, catalasa y oxidasa positiva, similares a Neisseria. Forman parte de la microbiota normal de las vías respiratorias superiores y cada vez se identifican más como causa de otitis media, sinusitis e infección broncopulmonar. En los últimos decenios este microorganismo ha recibido varios nombres, entre ellos Micrococcus catarrhalis, Neisseria catarrhalis y Branhamella catarrhalis ${ }^{(43)}$.

En los últimos 20 a 30 años, esta bacteria se ha convertido en un patógeno verdadero y ahora se considera una causa importante asociado a infecciones de las vías respiratorias en niños y ancianos ${ }^{(57)}$. En hospederos inmunocomprometidos, la bacteria puede causar una variedad de infecciones graves como neumonía, endocarditis, sepsi y meningitis ${ }^{(58)}$. Además, se han descrito brotes hospitalarios de enfermedad respi- 
ratoria debida a este germen, por lo cual se considera un patógeno nosocomial(59).

Los estudios epidemiológicos de $M$. catarrhalis suelen ser difíciles. Sin embargo, el interés clínico es relativamente reciente, y muchos laboratorios no informan $M$. catarrhalis como un patógeno, especialmente cuando está presente otro patógeno como por ejemplo, S. pneumoniae o H. influenzae. Además, el aislamiento de M. catarrhalis a partir de esputos se hace difícil por la presencia de neiserias no patógena, por lo tanto, el uso de medios de cultivo selectivos podría ser importante ${ }^{(60)}$.

\section{Mycoplasma pneumoniae}

Los micoplasmas son bacterias pequeñas y pleomorficas, pertenecen a la familia Mycoplasmataceae. En la actualidad se sabe que han evolucionado de ancestros Gram positivos tipo Clostridios. Durante su evolución han perdido la pared celular rígida, por lo que difieren de otras bacterias y no es posible visualizarlas al microscopio con coloración de Gram, por lo cual no responden al tratamiento con $\beta$-lactámicos ${ }^{(48,61)}$. La célula individual está delimitada por una membrana trilaminar compuesta de esteroles y su genoma es bastante pequeño, hasta el punto de poseer el más pequeño de las Eubacterias conocidas $^{(43)}$. M. pneumoniae posee un orgánulo de adherencia, que es una extensión delgada en un polo de la célula, con un centro electrodenso y un botón terminal. Estas estructuras forman parte del citoesqueleto del Mycoplasma, compuesto por una red de proteínas. Agrupada en el extremo del orgánulo de adherencia se encuentra una proteína de 169 kDa asociada con la membrana, denominada PI, que es la principal citoadhesina que determina la adherencia a las células blanco. Como la citoadherencia es el primer paso para la infección de las superficies mucosas susceptibles, estas proteínas representan verdaderos factores de virulencia ${ }^{(43)}$.

La supervivencia de $M$. pneumoniae inicialmente depende de la citoadherencia al epitelio respiratorio del huésped. Después de la adhesión, se multiplica con el fin de establecer una infección, que implica colonización e inflamación adicional de otros tejidos. Actúa localmente causando destrucción tisular y parece producir la mayoría de sus cambios fisiológicos y citolíticos mientras permanece en el espacio extracelular. Elabora productos citotóxicos como peróxido de hidrógeno y anión superóxido, y su acumulación es la probable causa de la toxicidad celular. La parálisis de los cilios respiratorios, otra consecuencia de la infección por este microorganismo, podría explicar la tos irritante que frecuentemente persiste por días o semanas después de la recuperación de la enfermedad aguda(62).

Aunque más de 200 especies de Mycoplasmas se han descubierto en los animales y el hombre, hasta la fecha existen 16 especies reconocidas como patógenos humano; de ellos $M$. pneumoniae es el patógeno más importante y por tanto el más estudiado. La infección por este germen muestra una variedad de manifestaciones clínicas, que van desde la infección asintomática hasta neumonía letal pudiendo tener manifestaciones extrapulmonares. La neumonía por este agente ha sido reportada en 10 a $40 \%$ de los casos de NAC, y los niños son el grupo más susceptible ${ }^{(63,64)}$. Sin embargo, la proporción de casos aumenta significativamente durante el verano en países con clima templado, debido a una menor incidencia de otros patógenos ${ }^{(65)}$.

Casi todas las infecciones causadas por M. pneumoniae son relativamente leves e incluyen faringitis, traqueobronquitis, bronquiolitis y crup. Las manifestaciones clínicas se desarrollan gradualmente, en un período de varios días. En menos del 10\% de los casos el cuadro clínico evoluciona a NAC ${ }^{(66)}$.

\section{Chlamydophila pneumoniae}

Es una bacteria pequeña con estructura similar a las bacterias Gram negativas, pertenece a la familia Chlamydiaceae, intracelular obligado de células de mamíferos y aves. Pertenece al grupo de patógenos llamados "atípicas". Posee un ciclo de vida único en el que se distinguen dos formas, el cuerpo elemental metabólicamente inactivo, con capacidad infectante que puede encontrarse extracelularmente y el cuerpo reticular metabólicamente activo, intracelular. Puede causar enfermedad invasiva mediante la internalización del cuerpo elemental por endocitosis después de reconocer un receptor específico. Se localiza en una vacuola citoplasmática, en el interior de la cual se transforma en un cuerpo reticular, que se replica por fisión binaria y se transforma de nuevo en cuerpos elementales, estos salen de la célula con o sin la destrucción de la misma(43,48).

Se ha demostrado que la infección por $C$. pneumoniae se encuentra distribuida en todos los grupos de edad y zonas geográficas. Debido a la dificultad de establecer una estrategia diagnóstica eficaz, las estimaciones de la frecuencia de este microorganismo en NAC varían de 0 a 44\%. Este agente puede diseminarse entre las familias y los grupos sociales cercanos. El papel de la colonización o estado de portador no es claro(67).

En los adultos, estos patógenos se asocian comúnmente con síntomas no respiratorios y con enfermedad pulmonar bilateral, en comparación con la presentación clásica de la neumonía lobar neumocócica; además, de la infección asintomática, la presentación clínica habitual de la infección por $C$. pneumoniae es significativa en los niños y cursa con neumonía leve indistinguible de las causadas por otros organismos. No parece causar "neumonía atípica", como en los adultos. La enfermedad grave y el derrame pleural son raros en niños inmunocompetentes. La infección por $C$. pneumoniae puede ser responsable de hasta $20 \%$ de las presentaciones con el síndrome torácico agudo en niños con anemia falciforme ${ }^{(67)}$.

Ha sido difícil esclarecer el papel de la infección por $C$. pneumoniae en la enfermedad aguda de las vías respiratorias inferiores, muchos estudios por métodos serológicos o métodos directos han identificado en el contexto de la enfermedad asociación con otro patógeno respiratorio(68). Los estudios sobre diagnóstico de la infección por C. pneumoniae son difíciles de interpretar. No existen pruebas gold estándar disponibles y se han aplicado diferentes técnicas con resultados muy discordantes. Además, las técnicas microbiológicas para identificar el microorganismo directamente en muestras clínicas siguen siendo rudimentarias ${ }^{(67)}$.

En conclusión, los virus respiratorios, principalmente el VRS es el germen más importantes como agente etiológico de NAC entre los lactantes. Las bacterias más frecuentemente identificadas son: S. pneumoniae y $M$. pneumoniae. Debido 
a la vacunación masiva contra $H$. influenzae, se ha modificado su frecuencia en los últimos años ${ }^{(1)}$. La vigilancia epidemiológica de la etiología de NAC en la población pediátrica se hace imperativa, para poder ajustar las directrices en cuanto a diagnóstico, tratamiento y medidas de control se refiere ${ }^{(25)}$.

\section{REFERENCIAS}

I. Herrera-Rodríguez D, Mariño C, Ramírez E, López Juan, Vélez C. Adenovirus en Niños Menores de Cinco Años. Patrones de Circulación, Características Clínicas y Epidemiológicas en Colombia, 1997-2003. Rev Salud Pública 2007; 9: 420-9.

2. Chen CJ, Lin PY, Tsai MH, Huang CG, Tsao KC, Wong KS, et al. Etiology of Community-acquired Pneumonia in Hospitalized Children in Northern Taiwan. Pediatr Infect Dis J 2012; 31 : el $96-$ 201.

3. Padilla J, Rojas R, Tantaleán FJ, Suárez V, Cabezas C, et al. Perfil etiológico de la neumonía adquirida en la comunidad en niños de 2 a 59 meses en dos zonas ecológicamente distintas del Perú. Arch argent pediatr 2010; 108: 516-23.

4. Reducción de la mortalidad en la niñez, nota descriptiva $N^{\circ} 178$, 20 I 2. http://www.who.int/mediacentre/factsheets/fs I 78/es/

5. Estadística sanitaria Organización Mundial de la Salud (OMS) 2011 . http://www.who.int/gho/publications/world_health_statistics/20 I I/ es/

6. Gentile A, Bardach A, Ciapponi A, García-Marti S, Aruj P, Glujovsky $D$, et al. Epidemiology of community-acquired pneumonia in children of Latin America and the Caribbean: a systematic review and meta-analysis. Int J Infect Dis 2012; 16: e5-15.

7. Indicadores de Salud Colombia 2008. http://www.paho.org/col/ index.php?option $=$ com_content\&view $=$ article\&id $=25 \&$ Item id $=135$

8. Martín A, M-PD, Alfayate D, Couceiro J, García M, Korta J. Etiología y diagnóstico de la neumonía adquirida en la comunidad y sus formas complicadas. Anales de pediatría 20 12; 76: I 62 el - 18.

9. Neumonía-Nota descriptiva $N^{\circ} 331$. Agosto de 2012. http://www. who.int/mediacentre/factsheets/fs33l/es/

10. Alcon A FN, Torres A. I. Pathophysiology of pneumonia. Clin Chest Med 2005; 26: 39-46.

1 I. Waites K. New concepts of Mycoplasma pneumoniae infections in children. Pediatr Pulmonol 2003; 36: 267- 78.

12. Klein J. Bacterial Pneumonias. Textbook of Pediatric Infectious Diseases Philadelphia: Saunders Elsevier 2009; pag. 302-14.

13. Consenso de la Sociedad Latinoamericana de Infectología Pediátrica (SLIPE) sobre Neumonía Adquirida en la Comunidad (NAC. [updated Sep 8th 2010; cited 2010 Oct I5th]; Available from: http://www.slipe.org/pdf/ConsensoNACninosSLIPE_8sept20 I 0. pdf?idNoticia =78).

14. Ferrari AM, Pirez C, Martínez A, Algorta A, Chamorro F, Guala J. Etiología de la Neumonía Bacteriana Adquirida en la Comunidad en Niños Hospitalizados: Uruguay 1998-2004. Rev Chil Infectol 2007; 24: 40-7.

15. Juvén T, Mertsola J, Waris M, Leinonen M, Meurman O, Roivainen $M$, et al. Etiology of community-acquired pneumonia in 254 hospitalized children. Pediatr Infect Dis J 2000; 19: 293-8.

16. Navarro M, Gómez P, Durán D. Neumonías bacterianas e infección respiratoria por Mycoplasma. Tratado de Neumología Infantil de Nicolás Cobos Barroso y Eduardo González PérezYarza: ERGON 2003; pág 405-26.
17. Muñoz JD. Neumonía severa adquirida en la comunidad. En: Martínez Y, Lince R, Quevedo A, editores. El niño en estado crítico. 2ed; 201 I; pág. 102-9.

18. Lee JH, Chun JK, Kim DS, Park Y, Choi JR, Kim HS. Identification of adenovirus, influenza virus, parainfluenza virus, and respiratory syncytial virus by two kinds of multiplex polymerase chain reaction (PCR) and a shell vial culture in pediatric patients with viral pneumonia. Yonsei Med J. 5 I. Korea South 20 I0; pág. 76I-7.

19. Valencia M, Bernal C, Morales $O$, Botero J. Neumonía adquirida en la comunidad en lactantes y preescolares del municipio de Turbo, Antioquia. IATREIA 2004; 17: 339-46.

20. Ferrari CAM, Pirez GMC, Martínez AA, Algorta RG, Chamorro VF, Guala BMJ, et al. Etiología de la neumonía bacteriana adquirida en la comunidad en niños hospitalizados: Uruguay 1998-2004. Rev Chil Infectol 2007; 24: 40-7.

21. Jartti T, Jartti L, Peltola V, Waris M, Ruuskanen O. Identification of respiratory viruses in asymptomatic subjects: asymptomatic respiratory viral infections. Pediatr Infect Dis J 2008; 27: I $103-7$.

22. Honkinen M, Lahti E, Osterback R, Ruuskanen O, Waris M. Viruses and bacteria in sputum samples of children with communityacquired pneumonia. Clin Microbiol Infect 20 I2; 18: 300-7.

23. Lee PI, Chiu CH, Chen PY, Lee CY, Lin TY. Guidelines for the management of community-acquired pneumonia in children. Acta Paediatr Taiwan 2007; 48: 167-80.

24. Martínez G. Neumonía Bacteriana. In: Hernández E. YM. Editor. Enfermedades Respiratorias Pediátricas 2002; pág. 255-80.

25. Nascimento-Carvalho CM, Cardoso MR, Barral A, Araujo-Neto CA, Oliveira JR, Sobral LS, et al. Seasonal patterns of viral and bacterial infections among children hospitalized with communityacquired pneumonia in a tropical region. Scand J Infect Dis 2010; 42: 839-44.

26. Don M, Fasoli L, Paldanius M, Vainionpaa R, Kleemola M, Raty R, et al. Aetiology of community-acquired pneumonia: serological results of a paediatric survey. Scand J Infect Dis 37. Sweden 2005; pág. 806- 12.

27. Heiskanen-Kosma T, Korppi M, Jokinen C, Kurki S, Heiskanen $\mathrm{L}$, Juvonen $\mathrm{H}$, et al. Etiology of childhood pneumonia: serologic results of a prospective, population-based study. Pediatr Infect Dis J 1998; 17: 986-91.

28. Rosete DP, Cabello C, Manjarrez ME. Patogenia de las infecciones respiratorias por virus. Rev Inst Nal Enf Resp Mex 20 12; I 5: 23954.

29. Pinto M, Ricardo. Virus respiratorio sincitial: aún un misterio. Rev Med Clin Condes 2007; 18: 155-64.

30. Ruuskanen O, Lahti E, Jennings LC, Murdoch DR. Viral pneumonia. Lancet 200 I; 377: 1264-75.

31. Marcone D, Videla C, Ekstrom J, Carballal G, Vidaurreta S, et al. Rinovirus: Frecuencia en niños con infección respiratoria aguda, no internados. Medicina (B. Aires) 2012; 72: 28-32.

32. Calvo-Rey C, Casas-Flechab I, Sánchez-Mateosa MF. Papel del rinovirus en las infecciones respiratorias en niños hospitalizados. Anales de pediatría (Barc) 2006; 65: 205- 10.

33. Savón-Valdés C, Acosta-Herrera B, González-Muñoz G, PiñónRamos A, González-Báez G, Goyenechea-Hernández A. Infección por rinovirus en niños hospitalizados menores de un año. Cuba 2006. Biomédica 2008; 19: 122-3.

34. Vega-Briceño LE, Potin M, Ferres M, Sánchez I. Características clínicas y epidemiológicas de la infección por virus parainfluenza en niños hospitalizados. Rev Chil Infectol 2007; 24: 377-83. 
35. Palerm-Caraballo L, González-Muñoz G, Savon-Valdés CE, Valdés Ramírez O, González-Báez G, Goyenechea-Hernández J, et al. Seroepidemiological surveillance of human parainfluenza viruses (HPIVs) types 2 and 3 in an infantile population selected in Havana City. Rev Cubana Med Trop 2005; 57: 169-74.

36. Luchsinger $\mathrm{V}$. Características del virus influenza y diagnóstico de laboratorio. Neumol Pediatr 2009; 4: 3-5.

37. Zamorano J, Budnik I. Manifestaciones clínicas de la infección por virus influenza en niños inmunocompetentes. Neumol Pediatr 2009; 4: 14-8.

38. Lee BE, Robinson JL, Khurana V, Pang XL, Preiksaitis JK, Fox JD. Enhanced identification of viral and atypical bacterial pathogens in lower respiratory tract samples with nucleic acid amplification tests. J Med Virol 2006; 78: 702-10.

39. García-García J, Ramos C. La influenza, un problema vigente de salud pública. Salud Publica Mex 2006; 48: 244-67.

40. Martin AA, Moreno-Pérez D, Miguelez SA, Gianzo JA, García ML, Murua JK, et al. Aetiology and diagnosis of community acquired pneumonia and its complicated forms. An Pediatr (Barc) 20I I; 76: 162 el- 18.

41. Crowcroft NS, Stein C, Duclos P, Birmingham M. How best to estimate the global burden of pertussis? Lancet Infect Dis 2003; 3: 4I3-8.

42. Geo F. Brooks, Janet S. Butel, Stephen A. Morse. Microbiología Médica de Jawetz, Melnick y Adelberg. Edicion: 25a. Editorial: Mc. Graw.Hill. 201 I. pág. 190-200.

43. Koneman EW, Allen SD, Janda WM, Schreckenberger PC, Winn WC. Diagnóstico Microbiológico. $6^{\mathrm{a}}$ ed. Ed. Médica Panamericana SA. Buenos Aires, 2008 pág. 161-200.

44. Weiser JN, Austrian R. Effect of pneumococcal polysaccharide vaccine on nonbacteremic pneumococcal pneumonia. Clin Infect Dis 2007; 44: I 139-40.

45. Hughes JM, La Montagne JR. Emerging infectious disease. J Infect Dis 1994; 170: 263-4.

46. Hortal M, Ruvinsky R, Rossi A, Agudelo Cl, Castañeda E, Brandileone C, et al. Impacto de Streptococcus pneumoniae en las neumonías del niño latinoamericano. Rev Panam Salud Pública 2000; 8: 185-95.

47. Trollfors B, Berg S, Backhaus E, Andersson R, Bossen Konradsen $H$. Invasive, paediatric, vaccine strains of Streptococcus pneumoniae: are there differences in clinical characteristics? Scand J Infect Dis 2009; 41: 84-7.

48. Gómez C. Infecciones respiratorias. En: Restrepo A, Robledo J, Leiderman E, Restrepo IM, Botero D, Bedoya V. Fundamentos de medicina. Enfermedades infecciosas. $6^{\mathrm{a}}$ ed. Corporación para Investigaciones Biológicas, CIB; 2003. p. |38-5।.

49. Davey S. Vacunas e inmunización. Situación actual. Organización Mundial de Salud-OMS. 2003. http://www. path.org/vaccine resources/files/wwwSOW_S.pdf.

50. Clark JE, Hammal D, Hampton F, Spencer D, Parker L. Epidemiology of community-acquired pneumonia in children seen in hospital. Epidemiol Infect 2007; 135: 262-9.
51. CDC. Progress toward elimination of Haemophilus influenzae type $\mathrm{b}$ invasive disease among infants and children-United States, 19982000. MMWR 2002; 51: 234-7.

52. Goicoechea Sáez M, Fullana Montoro AM, Momparler Carrasco P, Redondo Gallego MJ, Brines Solanes J, Bueno Canigral FJ. Enfermedad invasora por Haemophilus influenzae antes y después de la campaña de vacunación en la población infantil de la comunidad valenciana (1996-2000). Rev Esp Salud Pública 2002; 76: 197-206.

53. Balboa de Paz F RFJ, Blázquez Gamero D. Neumonía estafilocócica. Staphylococcus aureus pneumonia. Acta Pediatr Esp 2008; 66: $111-5$.

54. Saldías F, Yáñez J, Saldías $\vee$, Díaz $O$. Community-acquired pneumonia caused by Streptococcus pyogenes: report of one case. Rev Med Chile 2008; 136: I564-9.

55. Crum NF, Russell KL, Kaplan EL, Wallace MR, Wu J, Ashtari P, et al. Pneumonia outbreak associated with group a Streptococcus species at a military training facility. Clin Infect Dis 2005; 40: 5 । I-8.

56. Cunningham MW. Pathogenesis of group A streptococcal infections and their sequelae. Adv Exp Med Biol 2008; 609: 29-42.

57. Enright MC, McKenzie H. Moraxella (Branhamella) catarrhalisclinical and molecular aspects of a rediscovered pathogen. J Med Microbiol 1997; 46: 360-7I.

58. Richards SJ, Greening AP, Enright MC, Morgan MG, McKenzie $\mathrm{H}$. Outbreak of Moraxella catarrhalis in a respiratory unit. Thorax 1993; 48: 91-2.

59. Verduin CM, Hol C, Fleer A, van Dijk H, van Belkum A. Moraxella catarrhalis: from emerging to established pathogen. Clin Microbiol Rev 2002; I : 125-44.

60. Doern GV. Branhamella catarrhalis: phenotypic characteristics. Am J Med 1990; 88 (5A): 33S-5S.

61. Principi N, Esposito S. Emerging role of Mycoplasma pneumoniae and Chlamydia pneumoniae in paediatric respiratory-tract infections. Lancet Infect Dis 200 I ; : 334-44.

62. Carreazo J. Fisiopatología de las infecciones por Mycoplasma pneumoniae. Paediatrica 2003; 5: 101-8.

63. Atkinson TP, Balish MF, Waites KB. Epidemiology, clinical manifestations, pathogenesis and laboratory detection of Mycoplasma pneumoniae infections. FEMS Microbiol Rev 2008; 32: 956-73.

64. Lee KY. Pediatric respiratory infections by Mycoplasma pneumoniae. Expert Rev Anti Infect Ther 2008; 6: 509-21.

65. Waites KB, Talkington DF. Mycoplasma pneumoniae and its role as a human pathogen. Clin Microbiol Rev 2004; 17: 697-728.

66. Murray HW, Tuazon C. Atypical pneumonias. Med Clin North Am 1980; 64: 507-27.

67. Wolf J, Daley AJ. Microbiological aspects of bacterial lower respiratory tract illness in children: atypical pathogens. Paediatr Respir Rev 2007; 8: 212-9.

68. Miyashita N, Niki Y, Nakajima M, Fukano H, Matsushima T. Prevalence of asymptomatic infection with Chlamydia pneumoniae in subjectively healthy adults. Chest 2001; I19: 1416-9. 